\title{
Cover crops as a tool to reduce reliance on intensive tillage and nitrogen fertilization in conventional arable cropping systems
}

\author{
Wittwer, Raphaël A ; van der Heijden, Marcel G A
}

DOI: https://doi.org/10.1016/j.fcr.2020.107736

Posted at the Zurich Open Repository and Archive, University of Zurich ZORA URL: https://doi.org/10.5167/uzh-193823

Journal Article

Accepted Version

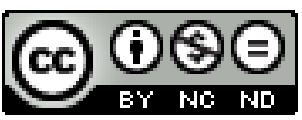

The following work is licensed under a Creative Commons: Attribution-NonCommercial-NoDerivatives 4.0 International (CC BY-NC-ND 4.0) License.

Originally published at:

Wittwer, Raphaël A; van der Heijden, Marcel G A (2020). Cover crops as a tool to reduce reliance on intensive tillage and nitrogen fertilization in conventional arable cropping systems. Field Crops Research, 249:107736.

DOI: https://doi.org/10.1016/j.fcr.2020.107736 
1 Cover crops as a tool to reduce reliance on intensive tillage and nitrogen fertilization in conventional arable cropping systems

3

4 Raphaël A. Wittwer ${ }^{1,2}$, Marcel G.A van der Heijden ${ }^{1,2^{*}}$.

$5{ }^{1}$ Plant-Soil-Interactions group, Division of Agroecology and Environment, Agroscope,

6 Reckenholzstrasse 191, CH-8046 Zurich, Switzerland

$7 \quad{ }^{2}$ Department of Plant and Microbial Biology, University of Zurich, Zollikersrasse 107, 8008

8 Zurich, Switzerland

$9 \quad$ *corresponding author: Tel.: +41 58468 7278. E-mail address:

10 marcel.venderheijden@agroscope.admin.ch .

Highlights

- Nitrogen fertilization can be reduced after legume cover crops without compromising yield.

- Tillage intensity can be reduced only in combination with cover cropping.

- Weed control under reduced tillage is challenging, even with cover crops.

- Maize depleted nitrogen in absence of a legume cover crop.

- Aerial spectral imagery provided insight into crop growth dynamics. 
Cover crops are often recommended as a valuable practice to develop more sustainable cropping systems but, despite many benefits, their adoption in practice is still limited mainly because the effects on productivity and economic return are variable. Furthermore, it is still unclear under which combinations with other management practices (e.g. tillage, fertilization, weed control) cover crops can provide the highest paybacks.

Here we tested whether cover crops are a suitable management tool to reduce fertilizer input, tillage intensity and herbicide use in Swiss arable cropping systems. We compared the effects of four different cover crop treatments (fallow, radish, subterranean clover and hairy vetch) on maize at two fertilization levels combined with three levels of tillage intensity. To unravel the effects of cover crops on maize growth, we assessed vegetation dynamics using the Normalized Differential Vegetation Index (NDVI) from aerial spectral imagery. Cover crops on average increased yields by $12 \%(+7 \%$ to $+20 \%)$ and cover crop effects depended on tillage intensity, fertilization level and cover crop treatment for most of the assessed maize parameters. Best results were obtained with hairy vetch, which increased maize $\mathrm{N}$ uptake by $79 \mathrm{~kg} \mathrm{ha}^{-1}$ on average. As a consequence, at least combinations of two of the three targeted inputs (tillage, fertilization and herbicides) could be successfully reduced, e.g. tillage and fertilization under no tillage or tillage and herbicides under reduced tillage. Even under intensive tillage, both legume cover crops allowed a reduction of fertilization without compromising yield. Spectral imagery analysis showed that legume cover crops compensated for delayed $\mathrm{N}$ availability in reduced and no tillage systems and cover crops contributed to enhanced $\mathrm{N}$ uptake and crop growth later in the season. We provide evidence that cover crop based cropping systems can be used to reduce synthetic inputs and tillage without compromising yield, thus presenting an example of ecological 
44 when adopting cover cropping in order to maintain or increase productivity with reduced 45 anthropogenic inputs under conventional cropping.

46 Keywords: conservation agriculture; drone imagery; ecological intensification; maize; hairy 47 vetch 
49 The intensification of arable production have made a substantial contribution to increased world food production over the last 50 years (Tilman et al., 2002). However, current agricultural practices have also given rise to environmental concerns regarding decreased biodiversity, reduced water quality, and degraded soil quality (Stoate et al., 2001). Although the use of mineral fertilizers and pesticides has led to a considerable increase in productivity, arguably the main ecosystem service provided by agriculture, this has been at the cost of other regulating and supporting services provided by agro-ecosystems (Power, 2010). The internal regulation of nutrient cycles, the natural control of pests and diseases, and the abundance and diversity of soil organisms are often downregulated in intensively managed fields. As a result, high agricultural productivity becomes dependent on anthropogenic-synthetic inputs and is no longer sustainable in the long-term (Geiger et al., 2010; Tsiafouli et al., 2015). Ideally, a sustainable system will maintain the right balance between external inputs and ecosystem service delivery, thus providing high productivity based on optimized internal regulatory processes and resilience of the system (Bender et al., 2016). This goal could be achieved by including agricultural practices that promote regulating and supporting ecosystem services and preserving soil quality, also called ecological engineering. One example of this is conservation agriculture (CA), which principles include reduced tillage, improved crop rotation, and permanent soil coverage (Teasdale et al., 2007; Hobbs et al., 2008; Doltra and Olesen, 2013). Although CA contributes to soil conservation, reduced consumption of fossil fuels, a reduced work load, and is widely propagated in the America's and Australia, adoption rates in Europe are still very low (Derpsch et al., 2010; Kertész and Madarász, 2014;

70 Casagrande et al., 2016). The main reasons why CA is not widely adopted in Europe include

71 the often more complex crop rotations (e.g. presence of ley), problems related to weed control, 72 and delayed spring nutrient mineralization. 
Another option to improve the sustainability of agricultural production is the use of cover crops.

Cover crops are grown between two main crops and are a crucial element of CA systems to reach an appropriate soil coverage during fallow period as well as maintain productivity (Hartwig and Ammon, 2002; Pittelkow et al., 2015; Marcillo and Miguez, 2017). Cover crops provide a range of ecosystem services, as they have been shown to protect soil against erosion, reduce the risk of surface and ground water pollution, improve soil structure, and promote soil biota (Dabney et al., 2001; Kohl et al., 2014; Schipanski et al., 2014; Blanco-Canqui et al., 2015). Moreover, cover crops play an important role in the management of nitrogen $(\mathrm{N})$ within arable cropping systems, either by preventing leaching losses (non-legume species) (De Notaris et al., 2018; Thapa et al., 2018) or by providing additional $\mathrm{N}$ input through biological fixation (legume species) (Thorup-Kristensen et al., 2003; Couëdel et al., 2018). Cereal-based systems, particularly maize, benefit greatly from additional $\mathrm{N}$ input by legume cover crops, as shown by several studies (Miguez and Bollero, 2005; Gabriel and Quemada, 2011; Liebman et al., 2012; Tosti et al., 2012; Komainda et al., 2017).

All these benefits have been extensively described as well as the importance of direct cover crop management, e.g. sowing and termination date or termination techniques (ThorupKristensen and Dresboll, 2010; Alonso-Ayuso et al., 2014; Radicetti et al., 2016; Osipitan et al., 2019). Cover crops have also been shown to be important when conservation tillage is applied or to reduce $\mathrm{N}$ applications. However, few studies have investigated to which extent cover crop based agro-ecosystem services are influenced by the combination of these management practices or, more generally, perform within defined cropping systems. (Wittwer et al., 2017). Both tillage and fertilization greatly influence soil properties and processes, such as organic matter mineralization (Balesdent et al., 1990; Kandeler et al., 1999) and weed abundance, which in turn influence crop nutrition and productivity (Shelton et al., 2017). For example, it is still unclear if and to which extent cover crops can reduce the reliance on fertilizers under different tillage intensities without impairing crop yield. Moreover, earlier 
studies reported that legume cover crops can fix more than $100 \mathrm{~kg} \mathrm{~N} \mathrm{ha}^{-1}$ year $^{-1}$, but it is still difficult to predict how much of this $\mathrm{N}$ can be effectively used by the following crop (ThorupKristensen et al., 2003; Büchi et al., 2015). Additionally, cover crops could suppress weeds and thus have the potential to reduce tillage and herbicide use, especially if cover crops can be easily managed before the main crop is planted (Dorn et al., 2015). Thus, it is increasingly important to gain a clearer understanding of the interactions between cover cropping and other field management practices, such as tillage intensity or fertilization in an effort to optimize cover crop effects on productivity and profitability, and thereby achieve a wider adoption of this practice by farmers as a mean of ecological intensification (Roesch-McNally et al., 2017).

Consequently, this study focuses on the interactions between tillage intensity, $\mathrm{N}$ fertilization and cover cropping in Swiss conventional arable crop production. Two replicated field experiments were conducted during the years 2012-2014 and 2013-2015 with a crop sequence of winter wheat, cover crops, and maize in Eastern Switzerland. The effect of three different cover crops (hairy vetch (Vicia villosa), oilseed radish (Raphanus sativus) and subterranean clover (Trifolium subterraneum)) were compared to fallow combined with three levels of tillage intensity coupled with weed control strategy (intensive tillage with herbicides, reduced tillage without herbicides, and no tillage with herbicides) and two levels of $\mathrm{N}$ fertilization.

The main aim of the study was to evaluate the extent to which the use of cover crops can decrease dependency on intensive tillage, synthetic $\mathrm{N}$ fertilization, and herbicides. Thus, based on the assumptions that:

i) cover crops help to reduce tillage intensity,

ii) additional $\mathrm{N}$ input provided by legume cover crops can partly replace the addition of synthetic $\mathrm{N}$ fertilizer, and

iii) the combination of cover cropping and reduced tillage allows a reduced use of herbicides, 
we aimed to identify best combinations of the investigated management practices to sustain

125 productivity but reduce anthropogenic inputs.

\section{Materials and methods}

\subsection{Study site and field experiments}

130 Two field experiments were conducted during the years 2012-14 (Experiment I) and 2013-15

(Experiment II) at the research station Agroscope in Tänikon, Switzerland (47 $28^{\prime} 50^{\prime}$ ' N, $8^{\circ} 54^{\prime} 25^{\prime}$ E, $537 \mathrm{~m}$ a.s.1.). The top soil of both experiments is classified as sandy loam, containing on average $21 \%$ clay, $35 \%$ silt and $44 \%$ sand, with $2.1 \%$ organic carbon content, $0.23 \%$ total nitrogen content, and it had a $\mathrm{pH}\left(\mathrm{H}_{2} \mathrm{O}\right)$ of 7 . The long-term (1981-2010) mean annual temperature is $8.7^{\circ} \mathrm{C}$, while annual precipitation averages $1184 \mathrm{~mm}$. Weather conditions in the experimental years did not substantially deviate from the long-term averages $\left(2014: 10^{\circ} \mathrm{C}\right.$ and $1113 \mathrm{~mm}, 2015: 9.8^{\circ} \mathrm{C}$ and $927 \mathrm{~mm}$ ). However, a slight drought period occurred from July to September 2015 (Supplementary Figure S1).

The two experiments have exactly the same experimental design and the only difference is the start date, where experiment II starts one year later. This was done to obtain a more robust understanding of the treatment effects across years. The two experiments (I and II) were arranged in a strip-split-plot design with four replicates. Factor I (main plots, only applied to maize) was three levels of tillage intensity coupled with weed management strategy: 1)

144 intensive tillage (IT) by mouldboard ploughing and use of post-emergence herbicides, 2) no145 tillage (NT) with the use of glyphosate and post-emergence herbicides, and 3) reduced tillage 146 (RT) by shallow non-inversion tillage and mechanical weed control in maize. Factor II (subplot 147 CC) consisted of four different cover crop treatments: 1) oilseed radish (cv. Pegletta) as a fast 148 growing non-legume cover crop (RS), 2) hairy vetch (cv. Hungvillosa) as a high biomass 149 overwintering legume cover crop (VV), 3) subterranean clover (cv. Campeda) as a self-re- 
seeding specie, which was already undersown in the previous crop (winter wheat) as living mulch and should also act as cover crop before maize (TS), and 4) fallow (as control). Although, the aim was that subterranean clover can re-establish by itself, it was re-sown after winter wheat harvest because the re-seeding rate was too low for appropriate soil coverage. Factor III (subplot F) was ammonium nitrate application to the main crops either at the norm (normN) or half rate (halfN) of what is recommended to farmers in Switzerland (Flisch et al., 2009). The combination of these three factors resulted in 24 treatment-combinations and 96 plots per experiment. The size of the main plot (tillage) was $384 \mathrm{~m}^{2}(12 \times 32 \mathrm{~m})$ and the smallest plot size was $48 \mathrm{~m}^{2}(6 \times 8 \mathrm{~m})$ (Figure 1).

\subsection{Crop management}

The two experiments consisted of a winter wheat - cover crop - maize crop sequence. In the years preceding the experiments, the fields were managed conventionally and annually ploughed 20-25 cm deep. Forage pea (Pisum sativum subsp. arvense) was grown prior to the start of the experiments, and, after ploughing the experimental field, winter wheat (Triticum aestivum L. cv. 'CH Claro') was sown early October (5.20.12 in Exp. I and 3.10.13 in Exp. II) either as pure crop (control, RS and VV cover crop treatments) or intercropped with subterranean clover (TS treatment). Weed control in wheat was performed by herbicide application in the pure wheat plots (control, RS and VV cover crop treatments), whereas no weed control was performed in the intercropped wheat (TS treatment). The normN fertilization plots received a total of $140 \mathrm{~kg} \mathrm{~N} \mathrm{ha}^{-1}$ in three applications (70/30/40), and the halfN fertilization plots a total of $70 \mathrm{~kg} \mathrm{~N} \mathrm{ha}^{-1}$ in two applications (45/25). The results from the wheat-clover intercropping treatment have already been published (Radicetti et al., 2018), and in this study we focus on the effect of cover cropping, coupled with tillage and fertilization, on maize production. 
After wheat harvest (3.8.13 in Exp. I and 25.7.14 in Exp. II), the straw was removed from the plots and all three winter cover crops (RS, VV, and TS) were sown (21.8.13 in Exp. I and 7.8.14 in Exp. II) after a shallow stubble cultivation (rotary cultivator at $5 \mathrm{~cm}$ soil depth, also in the control plots). Cover crops and weeds in control plots were terminated the next spring by either tillage (IT and RT treatments, 18.5.14 in Exp. I and 13.5.15 in Exp. II) or by applying $1.44 \mathrm{~kg}$ $\mathrm{ha}^{-1}$ (active ingredient) glyphosate in the NT treatment (30.4.14 in Exp. I and 29.4.15 in Exp. II). The IT treatment consisted of mouldboard ploughing at $20 \mathrm{~cm}$ soil depth and a seed bed preparation with a rotary harrow at $5 \mathrm{~cm}$ soil depth. The $\mathrm{RT}$ treatment was performed with a precision cultivator (Weco-dyn, Friedrich Wenz $\mathrm{GmbH}$ ) in three passes: the first two passes at 2-3 $\mathrm{cm}$ and the third one at 5-6 $\mathrm{cm}$ soil depth. Cover crop biomass was mulched with a flail mower prior to tillage operations in the IT and RT treatments.

Maize (Zea mays L. cv. ' LG 30.222') was sown at the end of May (22.5.14 in Exp. I and 28.5.15 in Exp. II) with a row distance of $0.75 \mathrm{~m}$ and combined with an underfoot starterfertilization of $30 \mathrm{~kg} \mathrm{~N} \mathrm{ha}^{-1}$ in both fertilization treatments. The normN plots received an additional $60 \mathrm{~kg} \mathrm{~N} \mathrm{ha}^{-1}\left(90 \mathrm{~kg} \mathrm{~N}\right.$ in total) and the halfN plots additional $15 \mathrm{~kg} \mathrm{~N} \mathrm{ha}^{-1}(45 \mathrm{~kg} \mathrm{~N}$ in total) at maize growth stage BBCH15-17. Weeds during maize growth were controlled by herbicides in the IT and NT treatments, but were controlled mechanically by hoeing two times in the RT treatment. Primary tillage and post-emergence weed control were combined in one factor as they are both integrated part of weeding strategies. Indeed, herbicides are commonly applied in conventional systems and glyphosate application is still predominating in no tillage systems. The use of reduced tillage without herbicides was therefore designed in one hand to reduce tillage intensity and to avoid the use of glyphosate as well as post-emergence herbicides. Thus, the two factor-combinations $\mathrm{RT} / \mathrm{TS} / 50 \mathrm{~N}$ and $\mathrm{RT} / \mathrm{TS} / 100 \mathrm{~N}$ did not receive any herbicide during the experimental period and the other RT treatments no herbicides in maize only. Maize was harvested as whole plant (9.10.14 in Exp. I and 8.10.15 in Exp. II) and as grain (30.10.14 
in Exp. I and 28.10.15 in Exp. II). Additional information regarding field operations (dates, amount applied, and machinery) can be found in supplementary Table S1.

\subsection{Measurements}

Cover crop growth was monitored by evaluating the percentage of soil covered by cover crop species and weeds at 20, 30 and 60 days after sowing (DAS). Two pictures per plot were taken at $180 \mathrm{~cm}$ height, covering $1 \mathrm{~m}^{2}$ ground surface, using a bipod stand. Total plant soil cover was then determined with the program ASSESS 2.0 (Lamari, 2008) based on colour saturation. The percentage of soil covered by cover crops versus weeds was then determined visually based on the pictures. Additionally, cover crop and weed biomass were determined before termination in spring by cutting the plants $1 \mathrm{~cm}$ above the soil surface within two randomly placed quadrants $(50 \mathrm{~cm} \times 50 \mathrm{~cm})$ per subplot. Weed and cover crop species were sorted for each sample before dry weight determination.

In maize, weed density and biomass were assessed at the end of maize flowering (BBCH69) to determine weed pressure in four quadrants $(50 \mathrm{~cm}$ x $50 \mathrm{~cm})$ per subplot. Mean values - for cover, density, and biomass data - were calculated for each subplot and used for the analyses.

Maize biomass (whole plant) and grain yield were determined by harvesting two rows in each plot (7 m length) with adapted plot-sized combine harvesters. Biomass and grain weights were directly measured by the harvesters and a subsample was collected per plot for dry matter and nutrient content determination. Dry matter content was determined by oven-drying plant material (cover crops, weeds, maize biomass and grain) at $105^{\circ} \mathrm{C}$ for 30 hours to adjust yield and biomass data to $\mathrm{t}$ dry matter $(\mathrm{DM}) \mathrm{ha}^{-1}$. Plant materials for nutrient analyses were ovendried at $60^{\circ} \mathrm{C}$ and finely ground. The $\mathrm{N}$ and $\mathrm{C}$ concentrations of cover crop biomass as well as $\mathrm{N}$ concentration of maize biomass and grain were then determined using elemental analysis by the Dumas method (Dumas, 1831). 
To assess the impact of the treatment combinations on the $\mathrm{N}$ status of the different cropping systems, we calculated the overall $\mathrm{N}$ balance as the difference between the total amount of $\mathrm{N}$ input and the amount of $\mathrm{N}$ exported at harvest. Here, $\mathrm{N}$ input is the combination between the $\mathrm{N}$ applied as mineral fertilizer (Nfert) and an estimation of $\mathrm{N}$ fixed by the legume cover crops (Nfix). Nfix was calculated as the $\mathrm{N}$ content in cover crops at termination multiplied by the percentage of $\mathrm{N}$ derived from the atmosphere (\%Ndfa) using values obtained by Büchi et al. (2015) for subterranean clover and hairy vetch in Switzerland. A positive N balance reflects an $\mathrm{N}$ surplus in the system and a negative balance implies that soil $\mathrm{N}$ was depleted. measured maize biomass $\mathrm{N}$ concentration and the critical $\mathrm{N}$ concentration (Ncrit.) calculated after Plénet and Lemaire (1999):

$$
\text { Ncrit. }=3.40 *{\text { (biomass })^{-0.37}}^{-0}
$$

In order to assess the contribution of cover crops to maize $\mathrm{N}$ nutrition, a cover crop $\mathrm{N}$ effect (NeffCC) was calculated (Tosti et al., 2012):

$$
\text { NeffCC,i }=\text { NuptCC,i }- \text { NuptCtr }
$$

240 where NuptCC, $\mathrm{i}$ is the $\mathrm{N}$ uptake of the main crop after a cover crop treatment and NuptCtr is 241 the $\mathrm{N}$ uptake of the main crop after the control treatment without cover crops. NeffCC values were calculated separately for the normN and halfN treatments. Additionally, the effect of $\mathrm{N}$ fertilization was calculated for the control plots by subtracting the $\mathrm{N}$ uptake of the halfN to the

$244 \mathrm{~N}$ uptake of the normN control plots for each tillage treatments.

245 Maize growth over the whole vegetation period was additionally monitored in experiment II 246 (2015) with the help of the Normalized Differential Vegetation Index (NDVI) obtained from unmanned aerial vehicle (UAV) imagery. NDVI is a well-recognized vegetation index (Tucker, 1979) that gives information about the status of a crop and is calculated based on the red and near-infrared (NIR) reflectance values of a crop canopy as follow:

$$
N D V I=(N I R-r e d) /(N I R+r e d)
$$


The experimental field was regularly monitored with a NIR modified camera (Canon S110 NIR,

$25212 \mathrm{MP}$ ), mounted on an automated fixed-wings UAV (eBee AG, senseFly), acquiring image 253 data in the near-infrared $(850 \mathrm{~nm})$, red $(625 \mathrm{~nm})$, and green $(550 \mathrm{~nm})$ spectral band at an average ground resolution of $2 \mathrm{~cm}$ per pixel. NDVI values at the plot level were then obtained for each flight by extracting the mean pixel value from NDVI index-maps created with the software PostflightTerra 3D (Pix4D, version 4.0.104) (Figure 1). Reflectance values for each pixels were calibrated with the camera settings by the software but no further radiometric calibration were performed. However, all flights were conducted under sunny conditions (without clouds) between $12 \mathrm{pm}$ and $2 \mathrm{pm}$ to reduce the impact of varying light conditions (Rasmussen et al., 2016). Maize growth curves were then obtained for each plot by fitting data with the loess 261 function (span=0.5) (Cleveland and Devlin, 1988) and the following physiological parameters 262 were then extracted for growth dynamics analyses (Fig. 2):

- MaxNDVI: the maximal NDVI value across the vegetation period

- Time integrated NDVI (TIN): daily (interpolated) integration of NDVI for the entire

\subsection{Statistical analysis}

271 Statistical analyses were all performed using R (R Core Team, 2014). Variance analyses on the assessed variables were performed using a strip-split-plot design with "tillage” (IT, NT, RT) as

273 the main plot, and "cover crop" (control, RS, TS, VV) and "fertilization" (normN, halfN) as 274 crossed-subplot in an ANOVA using linear mixed effects models (Kuznetsova et al., 2015). 275 The terms "experiment" and "replicate blocks within experiment" were included first in the model to account for their variation. Tillage, cover crop, and fertilization as well as their 
277 interactions were considered as fixed effects. Additionally, and because the experiments (I and 278 II) were performed in two years (2014 and 2015), the interactions of experiment (year) and the 279 three main factors were also included in the model. To identify suitable combination of cover 280 crops with tillage and fertilization, all treatments were additionally contrasted against the 281 reference treatment with intensive tillage, norm fertilization and no cover crop using the $\mathrm{R}$ 282 package lsmeans (Lenth, 2018). Contrasts were also used to test if the $\mathrm{N}$ balances differ from 0 283 (neutral $\mathrm{N}$ balance).Data were square root transformed when residual plots revealed deviation 284 from normality: that is for $\mathrm{N}$ content and $\mathrm{C} / \mathrm{N}$ ratio of cover crops, weed biomass in cover crops and both weed density measures in maize. For a better interpretation of the results these data were back-transformed in the figures and tables.

\section{Results}

\subsection{Cover crop performance}

All three cover crops established satisfactorily, with over $65 \%$ soil cover 60 days after sowing and significantly suppressed weeds compared to the control treatment (Table 1, Supplementary Table S2). Hairy vetch produced the highest biomass, with on average over $3 \mathrm{tha}^{-1}$ aboveground DM biomass, followed by subterranean clover with over $1 \mathrm{tha}^{-1}$. Both are overwintering species in contrast to oilseed radish, which was already terminated by frost during winter and left less than $1 \mathrm{t} \mathrm{ha}^{-1}$ biomass at termination in spring. Oilseed radish was still able to suppress weeds as well as hairy vetch until spring, whereas subterranean clover was not as efficient (Figure 3).

298 This could be partly due to the slower growth of clover in autumn. The cover crops differed significantly in their $\mathrm{N}$ content and $\mathrm{C} / \mathrm{N}$ ratio. Hairy vetch had the highest aboveground $\mathrm{N}$ content (over $140 \mathrm{~kg} \mathrm{~N} \mathrm{ha}^{-1}$ ) and the lowest $\mathrm{C} / \mathrm{N}$ ratio (10), followed by subterranean clover (32 $\mathrm{kg} \mathrm{N} \mathrm{ha}{ }^{-1}, \mathrm{C} / \mathrm{N}$ ratio of 15$)$ and radish $\left(8 \mathrm{~kg} \mathrm{~N} \mathrm{ha}^{-1}, \mathrm{C} / \mathrm{N}\right.$ ratio of 30) (Supplementary Table $\left.\mathrm{S} 2\right)$. 302 Overall, cover crop growth did not differ among the main plots and thus left similar conditions 
before differential tillage was applied to maize. More importantly, the two fertilization levels applied to the previous wheat crop had only minor effects on cover crop performance with overall a significant but slightly higher cover crop biomass after half fertilization in wheat $(+$ $\left.0.12 \mathrm{t} \mathrm{ha}^{-1}\right)$. This was mainly driven by a higher biomass for the legume cover crops under half fertilization (note that fertilization was applied to wheat but not directly applied to the cover crops). However, absolute differences were marginal.

The amount of aboveground atmospheric fixed $\mathrm{N}$ added by the legume cover crops was estimated at $125 \mathrm{~kg} \mathrm{~N} \mathrm{ha}^{-1}$ for hairy vetch and $19 \mathrm{~kg} \mathrm{~N} \mathrm{ha}^{-1}$ for subterranean clover (Supplementary Table S2). This large difference was due to the differences in biomass production and differences in the $\%$ Ndfa estimation factor, which was $88 \%$ for vetch and $61 \%$ for subterranean clover.

\subsection{Weed pressure}

Although weeds were successfully controlled during the cover cropping period, cover crops generally had little impact on weed pressure in maize. The largest and most significant differences were observed on weed biomass at maize flowering between the different tillage and weed control strategies (Table 1, Figure 3). In the reduced tillage treatment, with only mechanical weed control, weeds could not be fully controlled. In contrast weed biomass was very low in the intensive tillage treatment and in the NT treatment, where glyphosate was applied, in combination with post-emergence herbicides to control weeds.

Although no herbicides were applied in the TS treatment in the previous crop (wheat) and TS did not suppressed weeds as well as RS and VV during the cover crop period, this did not result in higher weed pressure in maize compared to the other cover crop treatments (Figure 3). N fertilization had no impact on weed pressure in maize and is therefore not displayed in Figure 3. 


\subsection{Maize productivity}

330 All three treatment factors (e.g. fertilization, tillage and cover crop) significantly influenced maize biomass and grain yield (Table 1). The highest maize grain yield was obtained after intensive tillage (9.8 $\mathrm{t} \mathrm{DM} \mathrm{ha}^{-1}$ averaged across the treatments), and it was slightly but not significantly lower under no tillage $\left(-10 \%, 8.9 \mathrm{t} \mathrm{DM} \mathrm{ha}^{-1}\right)$, and significantly lower after reduced 334 tillage without herbicide $\left(-22 \%, 7.6 \mathrm{t} \mathrm{DM} \mathrm{ha}^{-1}\right)$. Averaged across treatments, the norm $\mathrm{N}$ 335 fertilization rate increased grain yield by $0.75 \mathrm{t} \mathrm{DM} \mathrm{ha}^{-1}$ compared to half fertilization. Lastly, all three cover crop treatments significantly increased grain yield compared to fallow (8.0 t DM $\left.\mathrm{ha}^{-1}\right)$. The yield gain after cover crops was moderate after oilseed radish $\left(+7 \%, 8.5 \mathrm{t} \mathrm{DM} \mathrm{ha}^{-1}\right)$ and subterranean clover $\left(+11 \%, 8.9 \mathrm{t} \mathrm{DM} \mathrm{ha}^{-1}\right)$, and highest after hairy vetch $(+20 \%, 9.6 \mathrm{t} \mathrm{DM}$ $\left.339 \mathrm{ha}^{-1}\right)$.

340 Interestingly, significant interactions between cover crop and tillage, as well as cover crop and

341 fertilization were observed (Table 1) indicating that the effect of the cover crops on maize yield 342 depended on tillage treatment and fertilization treatment. For instance, consistent positive 343 effects of all cover crops were observed under no tillage compared to the fallow treatment (RS: $344+12 \%$, TS: $+14 \%$, VV: $+19 \%$ ), whereas only the two legume cover crop treatments increased 345 yield under IT (TS: $+9 \%$ and VV: $+10 \%$ ) and only hairy vetch significantly increased yield 346 under RT (VV: $+36 \%$ ). Moreover, no significant yield differences were observed between half 347 and norm fertilization within the legume cover crops (TS and VV), whereas significantly less 348 yield was obtained with half fertilization after fallow (-10\%) or radish $(-13 \%)$. Finally, all 349 treatment were contrasted against the reference system with intensive tillage, norm fertilization 350 and no cover crop. Several cover crop combinations with no tillage and reduced tillage and with 351 half fertilization under no tillage were not significantly different (Figure 4). This indicate that 352 inputs (e.g. fertilization or energy for tillage) could be successfully reduced but yield level was 353 maintained. 
354 Overall, yield level corresponded to mean yield expectation for Switzerland (10 $\left.\mathrm{tha}^{-1}\right)$ but was 355 higher in Exp. I (2014) than in Exp. II (2015). The reduced yield in 2015 could be partly explained by the lower precipitation amount in July and August 2015 (Supplementary Figure $\mathrm{S} 1$ ), which could have negatively influenced $\mathrm{N}$ availability. The interaction of year with fertilization also points in this direction (Supplementary Figure S2). However, tillage and cover crop effects did not vary between Exp. I and Exp. II as revealed by the absence of a significant interaction term between year and tillage or year and cover crop treatment.

\subsection{Maize nutrition and growth}

Similar to the yield results, the $\mathrm{N}$ uptake of maize was significantly influenced by tillage, cover crop and fertilization as well as the interaction between cover crop and tillage (Table 1, 2). The highest $\mathrm{N}$ uptake was observed under intensive tillage $\left(194 \mathrm{~kg} \mathrm{ha}^{-1} \pm 12 \mathrm{ci}\right)$, was not significantly lower under no tillage $\left(182 \mathrm{~kg} \mathrm{ha}^{-1} \pm 11 \mathrm{ci}\right)$ but significantly lower under reduced tillage (145 $\left.\mathrm{kg} \mathrm{ha}^{-1} \pm 12 \mathrm{ci}\right)$. Across all tillage and cover crop treatments, norm fertilization increased $\mathrm{N}$ uptake by $32 \mathrm{~kg} \mathrm{ha}^{-1}$. All cover crops also significantly increased maize $\mathrm{N}$ uptake compared to fallow (142 $\left.\mathrm{kg} \mathrm{ha}^{-1} \pm 10 \mathrm{ci}\right)$ and differed from each other with increasing effect

370 from radish to hairy vetch (RS: $157 \mathrm{~kg} \mathrm{ha}^{-1} \pm 11 \mathrm{ci}, \mathrm{TS}: 175 \mathrm{~kg} \mathrm{ha}^{-1} \pm 14 \mathrm{ci}, \mathrm{VV}: 221 \mathrm{~kg} \mathrm{ha}^{-1} \pm$ $371 \quad 12 \mathrm{ci})$

372 In order to assess the contribution of cover crops to maize $\mathrm{N}$ uptake, a cover crop $\mathrm{N}$ effect 373 (NeffCC) was calculated (see equation (2) in the methods). NeffCC was significantly different 374 among tillage and cover crop treatments but not among fertilization treatments (Table 1, 2). 375 Averaged across all tillage systems and compared to bare fallow, radish increased $\mathrm{N}$ uptake by $37615 \mathrm{~kg} \mathrm{ha}^{-1}$, subterranean clover by $33 \mathrm{~kg} \mathrm{ha}^{-1}$ and vetch by $79 \mathrm{~kg} \mathrm{ha}^{-1}$. In comparison, adding 45 $377 \mathrm{~kg} \mathrm{~N}$ as mineral fertilizer increased maize $\mathrm{N}$ uptake by $40 \mathrm{~kg} \mathrm{ha}^{-1}$ in the control plots without 378 cover crops, regardless of tillage intensity. However, the overall cover crop effect was highest 
379 under intensive tillage $\left(57 \mathrm{~kg} \mathrm{ha}^{-1} \pm 10 \mathrm{ci}\right)$ and significantly lower under no and reduced tillage 380 (NT: $37 \mathrm{~kg} \mathrm{ha}^{-1} \pm 7$ ci, RT: $33 \mathrm{~kg} \mathrm{ha}^{-1} \pm 11 \mathrm{ci}$ ).

381 The N Nutrition Index (NNI) for maize also revealed the importance of increased N uptake, as 382 only the treatments which attained an $\mathrm{N}$ uptake of about $215 \mathrm{~kg} \mathrm{~N} \mathrm{ha}^{-1}$ reached an NNI of 1 383 indicating no N limitation (Supplementary Figure S3). This was the case for almost all hairy 384 vetch plots (except under RT 50N) and maize following subterranean clover but with full 385 fertilization (except under RT) (Table 2).

386 To better understand the temporal dynamics behind treatment effects, maize growth was 387 monitored during the growing season in experiment II in 2015 based on NDVI from UAV 388 imagery (Figure 5). The tillage effect on early crop growth could be detected, as indicated by 389 the phenological parameter growth rate and max NDVI, which were significantly lower under 390 NT and RT than IT. Cover crops, and especially hairy vetch, positively influenced maize growth 391 throughout the growing season. This effect was most pronounced under reduced tillage and 392 intensive tillage early in the season (Figure 5, panel a, b, e, f) when treatments with hairy vetch 393 had enhanced maxNDVI, growth rate and TIN growth levels, more strongly under IT and RT 394 than NT. The positive effect of hairy vetch also appeared under no tillage later on (Figure 5, 395 panel c, d), as higher TINsen values were obtained under no tillage and the factor tillage was not anymore significant (Table 1, Supplementary Figure S4).

\subsection{N balance}

399 When assessing the impact of cover crops on overall $\mathrm{N}$ fluxes, we found that the effects were 400 similar among the tillage and fertilization treatments, with a positive $\mathrm{N}$ balance after hairy vetch $401(+42 \pm 14$ ci) and negative values for the other cover crop treatments (Control: $-35 \pm 14$ ci, RS: $-47 \pm 8$ ci, TS: $-36 \pm 11 \mathrm{ci}$ ) indicating that in those treatments maize removed more $\mathrm{N}$ from the soil compared to what was added. The higher $\mathrm{N}$ input from hairy vetch led to neutral $\mathrm{N}$ balance under half fertilization (except under RT) and a significantly positive $\mathrm{N}$ balance under norm $\mathrm{N}$ 
405 fertilization. In general, more neutral $\mathrm{N}$ balances were obtained under RT, mostly with full 406 fertilization, in contrast to either negative or positive $\mathrm{N}$ balances under IT and NT (Figure 6).

\section{Discussion}

410 It is known that cover crops can contribute to more sustainable cropping systems (Olesen et al., 411 2007; Schipanski et al., 2014; Giuliano et al., 2016). Although positive effects of cover crops on crop yield have been widely described (Tonitto et al., 2006; Marcillo and Miguez, 2017)

413 there is still poor adoption by farmers at a larger scale (Panagos et al., 2015; Seifert et al., 2018), 414 even if various national and regional incentives have recently initiated a positive trend and 415 higher integration of cover crops into rotations (Storr et al., 2019). Still, one key aspect to 416 increase the use of cover crops would be to improve the return on invest for farmers by optimizing cover crop based systems in order to increase profitability. This can be achieved either by reducing synthetic inputs (e.g. fertilizers, pesticides) and energy use (e.g. fuel for tillage) or by significantly increasing yield, also called ecological intensification. Moreover, for

420 farmers it is important to know under which conditions and with which field operations cover 421 crops are most beneficial to fulfill these expectations.

422 In our study, we focused on conventional cereal based cropping systems, which are one of the most widespread agricultural production systems in Europe or North America (FAO, 2019).

424 Cereal-based systems are characterized by high inputs of fertilizers and pesticides, and, at least 425 in Europe, relatively high tillage intensity. Finding ecological cropping practices that can 426 substitute a certain amount of inputs while maintaining productivity, also called ecological engineering, is therefore needed to design more sustainable cropping systems (Bender et al., 2016). We were particularly interested in understanding to which extent other field practices influence cover crop effects, and therefore finding most promising combinations of cover 430 cropping with tillage intensity, $\mathrm{N}$ fertilization and weed control strategy. 
431 Our results underline earlier findings that introducing cover crops allows a reduction of tillage 432 intensity (Mirsky et al., 2012; Wittwer et al., 2017; Büchi et al., 2018), as similar yield could 433 be achieved under no and reduced tillage compared to our reference treatment with intensive 434 tillage, full fertilization and no cover crop. We also found that legume cover crops can deliver 435 substantial amounts of $\mathrm{N}$ to the following crop, achieving similar yields even when $\mathrm{N}$ 436 fertilization was halved (Marcillo and Miguez, 2017). The addition of hairy vetch, a high 437 biomass legume cover crop, enhanced maize $\mathrm{N}$ uptake substantially (e.g. up to $109 \mathrm{~kg} \mathrm{~N} \mathrm{ha}^{-1}$ 438 additional uptake). Such effects were already observed in other studies (Tosti et al., 2012) but 439 it was still not well known that such results also apply for systems with reduced or no tillage 440 where mineralization rate are expected to be lower and residues left at the surface. Moreover, 441 the obtained results were consistent across different years, showing that these results were 442 repeatable and were not much influenced by inter-annual climatic variations at our experimental 443 site. Note that precipitations are not a main limiting factor in this region and that outcome could 444 be different in water limited regions.

445 Our results also indicate that $\mathrm{N}$ input by legume cover crops more positively impacted $\mathrm{N}$ balance 446 than mineral fertilization as neutral balances were achieved with hairy vetch under half 447 fertilization in contrast to full fertilization but no cover crop. Interestingly, the $\mathrm{N}$ balance for 448 maize was only positive in treatments after hairy vetch as a cover crop, while in all other 449 treatments the $\mathrm{N}$ balance was negative, indicating that maize removed more nitrogen from the soil compared to what was added. However, it is also important to note that a positive $\mathrm{N}$ balance 451 can also indicate a higher risk of $\mathrm{N}$ leaching, because $\mathrm{N}$ surplus and, in case of mineralisation, 452 enhanced soil $\mathrm{N}$ availability could potentially be lost if not synchronized with crop needs. On 453 the other hand, one advantage of legume derived $\mathrm{N}$ is that it is generally less prone to leaching 454 than mineral $\mathrm{N}$, as organic $\mathrm{N}$ is better retained in the soil (Crews and Peoples, 2005; Tosti et al., 2019). Thus even if an important fraction is not recovered in the crop (Almeida Acosta et al., 2011), it has a lower potential to be lost in the environment in contrast to mineral fertilizers 
457 (Hansen et al., 2019). Moreover, it was shown that high quality residues of cover crops can 458 support carbon- and nutrient-cycling management through litter feedbacks on decomposition 459 within cropping systems (Barel et al., 2018). Our results demonstrate that reducing $\mathrm{N}$ 460 fertilization coupled with a high biomass legume cover crop can achieve a neutral $\mathrm{N}$ balance 461 and thus sustain crop growth and $\mathrm{N}$ stocks in the system. The higher $\mathrm{N}$ balance for the treatment 462 combination with reduced tillage and hairy vetch as cover crop (RT VV) resulted in an $\mathrm{N}$ 463 surplus but this could be partly explained through the higher weed biomass in this treatment that probably has taken up a substantial amount of $\mathrm{N}$, which was not accounted in the $\mathrm{N}$ balance calculation.

Another important aspect to consider is the interest to reduce the global warming potential of cropping systems (e.g. reduce greenhouse gas emissions). Synthetic fertiliser use is one of the most important factors contributing to the global warming potential in Switzerland and Western Europe (Prechsl et al., 2017) because the production of synthetic nitrogen requires substantial amounts of energy (Woods et al., 2010). Moreover, $\mathrm{N}$ fertilization can significantly contribute to greenhouse gas emissions, especially through the production of the greenhouse gas nitrous 472 oxide (Skinner et al., 2019). In contrast, nitrous oxide emissions derived from legume cover 473 crops were shown to be low (Peyrard et al., 2016). Thus, the observation that nitrogen fixing cover crops can maintain yield at the same level, but with 50\% less nitrogen input is a promising observation which can help to reduce the contribution of arable cropping systems to global warming.

477 Earlier studies used drones and UAV imagery to monitor the development of crop yield and the 478 presence of nutrient deficiencies in crops at field scale (Maresma et al., 2016; Rasmussen et al., 479 2016). So far, UAV imagery has, to our knowledge, not been used to monitor the temporary effects of cover crops or differences between tillage intensities. We used the vegetation index NDVI as a proxy for crop growth and $\mathrm{N}$ uptake, which provided new insight behind the 482 temporal dynamic of cover crop effects under different tillage intensities. Overall, tillage mostly 
483 influenced early maize growth whereas the use of cover crops before maize had a significant 484 impact throughout the vegetation period. Based on the calculated phenological parameters, 485 legume cover crops could compensate for delayed $\mathrm{N}$ availability in reduced and no tillage systems (e.g. Grate, maxNDVI), prolonged N uptake and crop growth later in the season (e.g TIN, TINsen) and also compensated for reduced $\mathrm{N}$ fertilization. Based on these phenological 488 parameters, we also found that $\mathrm{N}$ availability from legume cover crops is greater when incorporated through tillage (e.g. in the tilled treatments) but also becomes available under no tillage later in the season. Generally, $\mathrm{N}$ release from buried plant residues is faster than surface placed residues, and the $\mathrm{N}$ concentration and $\mathrm{C} / \mathrm{N}$ ratio of the initial biomass are determinants for $\mathrm{N}$ release kinetic (Justes et al., 2009; Jahanzad et al., 2016). Further research could explore 493 how to adapt fertilization strategies in combination with legume cover crops to best fit crop 494 needs under reduced and no tillage. Finally, all calculated phenological indexes (maxNDVI, 495 Time Integrated NDVI and GrowthRate) significantly correlated with maize biomass and N uptake (Supplementary Figure S4). This also shows the potential of this approach to predict yield and $\mathrm{N}$ uptake over larger areas and therefore potentially be used to adapt fertilization 498 depending on crop needs (Maresma et al., 2016; Nuijten et al., 2019).

499 By combining tillage and weed management we also aimed at reducing herbicide use, 500 particularly under conservation tillage, as the application of herbicides is more and more criticized in society. Our results shows that cover crops did not significantly help to reduce weed pressure in the following maize crop. Although cover crops have the potential to keep weed pressure low, effects are very variable and depend even more on long-term management 504 and initial weed pressure (Osipitan et al., 2019; Reimer et al., 2019). The only treatment with reduced use of herbicides that could maintain yield was the combination of reduced tillage with hairy vetch and norm fertilization. The higher $\mathrm{N}$ input by hairy vetch have probably alleviated

507 the competition for nutrients by weeds in this treatment but it remains uncertain if this is a 508 viable practice in the long-term. 
In summary, this study demonstrated that best results on productivity were obtained with hairy

510 vetch as a cover crop similarly to Liebman et al. (2018). Moreover, at least combinations of two

511 of the three targeted inputs could be successfully reduced, e.g. tillage and fertilization under no

512 tillage or tillage and herbicides under reduced tillage. Even under intensive tillage, both legume

513 cover crops allowed a reduction of fertilization without compromising yield. However we did

514 not look at long-term effects of having repeated use of legumes as cover crops. Within the same

515 experiment we have found that legume species have the potential to harbor important pest and 516 disease as shown for nematodes (Schmidt et al., 2017) and for Fusarium fungi (Walder et al., 517 2017; Šišić et al., 2018). Thus, their repeated use should be planned with caution. On the other 518 hand, these risks as well as the amount of $\mathrm{N}$ delivered by cover crops could be managed by 519 using mixtures of species and make use of their associated multiple services (Amosse et al., 520 2015; Tribouillois et al., 2015; Finney et al., 2017; Couëdel et al., 2018).

521

\section{Conclusions}

523 This study demonstrates that legume cover crops can be used to partly replace fertiliser inputs 524 without compromising yield under intensive and no tillage, and thus confirms that cover 525 cropping has the ability to facilitate conservation agriculture and more extensive cropping practices. Compared to intensive tillage, full fertilisation and herbicide use, similar yields were obtained when either tillage intensity and/or fertilization were reduced in combination with a 528 legume cover crop. Thus, cover crops not only can be used to reduce nutrient leaching and 529 protect soil against erosion, they can also help to reduce fertiliser input and tillage while 530 maintaining typical productivity levels. Cover crops were not able to sufficiently control weeds 531 under reduced tillage and without herbicide but, here again, similar yield could be obtained 532 when $\mathrm{N}$ input from fertilization and legume cover crop was sufficient to alleviate negative 533 impact of increased weed pressure. 
534 Overall, this work demonstrates that cover crops are a suitable tool for ecological engineering, 535 but we recommend that farmers and farmer advisors consider the whole set of cropping 536 practices when adopting specific cover crops in order to maintain or increase productivity but 537 reduce inputs needs and costs.

538

\section{Acknowledgements}

540 We thank Werner Jossi for excellent practical support in setting up the experiment and we 541 would like to gratefully thank Grégoire Tombez for his help to implement UAV technology and 542 analyses for this study and for field work. This work was financed by the European Union FP7 543 Project n.289277: OSCAR (Optimising Subsidiary Crop Applications in Rotations) and 544 Agroscope. 
Almeida Acosta, J.A.d., Amado, T.J.C., Neergaard, A.d., Vinther, M., Silva, L.S.d., Silveira Nicoloso, R.d., 2011. Effect of $15 n$-labeled hairy vetch and nitrogen fertilization on maize nutrition and yield under no-tillage. Revista Brasileira de Ciência do Solo 35, 1337-1345.

Alonso-Ayuso, M., Luis Gabriel, J., Quemada, M., 2014. The Kill Date as a Management Tool for Cover Cropping Success. PLoS ONE 9, e109587.

Amosse, C., Dugon, J., Chassot, A., Courtois, N., Etter, J.-D., Fietier, A., Gruenig, K., Henggartner, W., Ramseier, H., Rossier, N., Sturny, W., Wittwer, R., Zimmermann, A., Jeangros, B., Charles, R., 2015. Behavior of different cover crops in a network of onfarm trials. Agrarforschung Schweiz 6, 524-533.

Balesdent, J., Mariotti, A., Boisgontier, D., 1990. Effect of tillage on soil organic carbon mineralization estimated from $13 \mathrm{C}$ abundance in maize fields. Journal of Soil Science 41, 587-596.

Barel, J.M., Kuyper, T.W., Paul, J., Boer, W., Cornelissen, J.H.C., De Deyn, G.B., Cheng, L., 2018. Winter cover crop legacy effects on litter decomposition act through litter quality and microbial community changes. Journal of Applied Ecology 56, 132-143.

Bender, S.F., Wagg, C., van der Heijden, M.G., 2016. An underground revolution: biodiversity and soil ecological engineering for agricultural sustainability. Trends in ecology \& evolution 31, 440-452.

Blanco-Canqui, H., Shaver, T.M., Lindquist, J.L., Shapiro, C.A., Elmore, R.W., Francis, C.A., Hergert, G.W., 2015. Cover Crops and Ecosystem Services: Insights from Studies in Temperate Soils. Agronomy Journal 107, 2449-2474.

Büchi, L., Gebhard, C.-A., Liebisch, F., Sinaj, S., Ramseier, H., Charles, R., 2015. Accumulation of biologically fixed nitrogen by legumes cultivated as cover crops in Switzerland. Plant Soil, 1-13.

Büchi, L., Wendling, M., Amossé, C., Necpalova, M., Charles, R., 2018. Importance of cover crops in alleviating negative effects of reduced soil tillage and promoting soil fertility in a winter wheat cropping system. Agriculture, Ecosystems \& Environment 256, 92-104.

Casagrande, M., Peigné, J., Payet, V., Mäder, P., Sans, F.X., Blanco-Moreno, J.M., Antichi, D., Bàrberi, P., Beeckman, A., Bigongiali, F., Cooper, J., Dierauer, H., Gascoyne, K., Grosse, M., Heß, J., Kranzler, A., Luik, A., Peetsmann, E., Surböck, A., Willekens, K., David, C., 2016. Organic farmers' motivations and challenges for adopting conservation agriculture in Europe. Org. Agr. 6, 281-295.

Cleveland, W.S., Devlin, S.J., 1988. Locally Weighted Regression: An Approach to Regression Analysis by Local Fitting. Journal of the American Statistical Association 83, 596-610.

Couëdel, A., Alletto, L., Tribouillois, H., Justes, É., 2018. Cover crop crucifer-legume mixtures provide effective nitrate catch crop and nitrogen green manure ecosystem services. Agriculture, Ecosystems \& Environment 254, 50-59.

Crews, T.E., Peoples, M.B., 2005. Can the synchrony of nitrogen supply and crop demand be improved in legume and fertilizer-based agroecosystems? A review. Nutr Cycl Agroecosyst 72, 101-120.

Dabney, S.M., Delgado, J.A., Reeves, D.W., 2001. Using winter cover crops to improve soil and water quality. Communications in Soil Science and Plant Analysis 32, 1221-1250.

De Notaris, C., Rasmussen, J., Sørensen, P., Olesen, J.E., 2018. Nitrogen leaching: A crop rotation perspective on the effect of $\mathrm{N}$ surplus, field management and use of catch crops. Agriculture, Ecosystems \& Environment 255, 1-11.

Derpsch, R., Friedrich, T., Kassam, A., Hongwen, L., 2010. Current Status of Adoption of NoTill Farming in the World and some of its Main Benefits. 
Doltra, J., Olesen, J.E., 2013. The role of catch crops in the ecological intensification of spring cereals in organic farming under Nordic climate. European Journal of Agronomy 44, 98-108.

Dorn, B., Jossi, W., van der Heijden, M.G.A., 2015. Weed suppression by cover crops: comparative on-farm experiments under integrated and organic conservation tillage. Weed Research, 586-597.

Dumas, J.B.A., 1831. Procédés de l'analyse organique. Ann. Chem. Phys 47, 198-213.

FAO, 2019. FAOSTAT statistical database. [Rome] : Food \& Agriculture Organization of the United Nations, c1997-.

Finney, D.M., Murrell, E.G., White, C.M., Baraibar, B., Barbercheck, M.E., Bradley, B.A., Cornelisse, S., Hunter, M.C., Kaye, J.P., Mortensen, D.A., 2017. Ecosystem services and disservices are bundled in simple and diverse cover cropping systems. Agricultural \& Environmental Letters 2.

Flisch, R., Sinaj, S., Charles, R., Richner, W., 2009. Grundlagen für die Düngung im Ackerund Futterbau (GRUDAF). Agrarforschung Schweiz 16.

Gabriel, J.L., Quemada, M., 2011. Replacing bare fallow with cover crops in a maize cropping system: Yield, $\mathrm{N}$ uptake and fertiliser fate. European Journal of Agronomy 34, 133-143.

Geiger, F., Bengtsson, J., Berendse, F., Weisser, W.W., Emmerson, M., Morales, M.B., Ceryngier, P., Liira, J., Tscharntke, T., Winqvist, C., Eggers, S., Bommarco, R., Part, T., Bretagnolle, V., Plantegenest, M., Clement, L.W., Dennis, C., Palmer, C., Onate, J.J., Guerrero, I., Hawro, V., Aavik, T., Thies, C., Flohre, A., Hanke, S., Fischer, C., Goedhart, P.W., Inchausti, P., 2010. Persistent negative effects of pesticides on biodiversity and biological control potential on European farmland. Basic and Applied Ecology 11, 97105.

Giuliano, S., Ryan, M.R., Véricel, G., Rametti, G., Perdrieux, F., Justes, E., Alletto, L., 2016. Low-input cropping systems to reduce input dependency and environmental impacts in maize production: A multi-criteria assessment. European Journal of Agronomy 76, 160175.

Hansen, S., Berland Frøseth, R., Stenberg, M., Stalenga, J., Olesen, J.E., Krauss, M., Radzikowski, P., Doltra, J., Nadeem, S., Torp, T., Pappa, V., Watson, C.A., 2019. Reviews and syntheses: Review of causes and sources of N2O emissions and NO3 leaching from organic arable crop rotations. Biogeosciences 16, 2795-2819.

Hartwig, N.L., Ammon, H.U., 2002. Cover crops and living mulches. Weed science 50, 688699.

Hobbs, P.R., Sayre, K., Gupta, R., 2008. The role of conservation agriculture in sustainable agriculture. Philosophical Transactions of the Royal Society B-Biological Sciences 363, 543-555.

Jahanzad, E., Barker, A.V., Hashemi, M., Eaton, T., Sadeghpour, A., Weis, S.A., 2016. Nitrogen Release Dynamics and Decomposition of Buried and Surface Cover Crop Residues. Agronomy Journal 108, 1735-1741.

Justes, E., Mary, B., Nicolardot, B., 2009. Quantifying and modelling C and N mineralization kinetics of catch crop residues in soil: parameterization of the residue decomposition module of STICS model for mature and non mature residues. Plant Soil 325, 171-185.

Kandeler, E., Tscherko, D., Spiegel, H., 1999. Long-term monitoring of microbial biomass, N mineralisation and enzyme activities of a Chernozem under different tillage management. Biology and fertility of soils 28, 343-351.

Kertész, Á., Madarász, B., 2014. Conservation Agriculture in Europe. International Soil and Water Conservation Research 2, 91-96.

Kohl, L., Oehl, F., van der Heijden, M.G.A., 2014. Agricultural practices indirectly influence plant productivity and ecosystem services through effects on soil biota. Ecological Applications 24, 1842-1853. 
Komainda, M., Taube, F., Kluß, C., Herrmann, A., 2017. Effects of catch crops on silage maize (Zea mays L.): yield, nitrogen uptake efficiency and losses. Nutr Cycl Agroecosyst 110, 51-69.

Kuznetsova, A., Brockhoff, P.B., Christensen, R.H.B., 2015. Package 'Imertest'. R package version 2.

Lamari, L., 2008. Assess 2.0 : image analysis software for plant disease quantification. American Phytopathological Society, St. Paul, MN.

Lenth, R., 2018. Package 'Ismeans'. The American Statistician 34, 216-221.

Liebman, A.M., Grossman, J., Brown, M., Wells, M.S., Reberg-Horton, S.C., Shi, W., 2018. Legume Cover Crops and Tillage Impact Nitrogen Dynamics in Organic Corn Production. Agronomy Journal 110, 1046-1057.

Liebman, M., Graef, R.L., Nettleton, D., Cambardella, C.A., 2012. Use of legume green manures as nitrogen sources for corn production. Renewable Agriculture and Food Systems 27, 180-191.

Marcillo, G.S., Miguez, F.E., 2017. Corn yield response to winter cover crops: An updated meta-analysis. Journal of Soil and Water Conservation 72, 226-239.

Maresma, Á., Ariza, M., Martínez, E., Lloveras, J., Martínez-Casasnovas, J., 2016. Analysis of Vegetation Indices to Determine Nitrogen Application and Yield Prediction in Maize (Zea mays L.) from a Standard UAV Service. Remote Sensing 8.

Miguez, F.E., Bollero, G.A., 2005. Review of corn yield response under winter cover cropping systems using meta-analytic methods. Crop Science 45, 2318-2329.

Mirsky, S.B., Ryan, M.R., Curran, W.S., Teasdale, J.R., Maul, J., Spargo, J.T., Moyer, J., Grantham, A.M., Weber, D., Way, T.R., Camargo, G.G., 2012. Conservation tillage issues: Cover crop-based organic rotational no-till grain production in the mid-Atlantic region, USA. Renewable Agriculture and Food Systems 27, 31-40.

Nuijten, R.J.G., Kooistra, L., De Deyn, G.B., 2019. Using Unmanned Aerial Systems (UAS) and Object-Based Image Analysis (OBIA) for Measuring Plant-Soil Feedback Effects on Crop Productivity. Drones 3, 54.

Olesen, J.E., Hansen, E.M., Askegaard, M., Rasmussen, I.A., 2007. The value of catch crops and organic manures for spring barley in organic arable farming. Field Crops Research $100,168-178$.

Osipitan, O.A., Dille, A., Assefa, Y., Radicetti, E., Ayeni, A., Knezevic, S.Z., 2019. Impact of Cover Crop Management on Level of Weed Suppression: A Meta-Analysis. Crop Science 59, 833-842.

Panagos, P., Borrelli, P., Meusburger, K., Alewell, C., Lugato, E., Montanarella, L., 2015. Estimating the soil erosion cover-management factor at the European scale. Land Use Policy 48, 38-50.

Peyrard, C., Mary, B., Perrin, P., Véricel, G., Gréhan, E., Justes, E., Léonard, J., 2016. N2O emissions of low input cropping systems as affected by legume and cover crops use. Agriculture, Ecosystems \& Environment 224, 145-156.

Pittelkow, C.M., Liang, X., Linquist, B.A., van Groenigen, K.J., Lee, J., Lundy, M.E., van Gestel, N., Six, J., Venterea, R.T., van Kessel, C., 2015. Productivity limits and potentials of the principles of conservation agriculture. Nature 517, 365-NIL_482.

Plénet, D., Lemaire, G., 1999. Relationships between dynamics of nitrogen uptake and dry matter accumulation in maize crops. Determination of critical $\mathrm{N}$ concentration. Plant Soil 216, 65-82.

Power, A.G., 2010. Ecosystem services and agriculture: tradeoffs and synergies. Philosophical transactions of the royal society B: biological sciences 365, 2959-2971.

Prechsl, U.E., Wittwer, R., van der Heijden, M.G., Lüscher, G., Jeanneret, P., Nemecek, T., 2017. Assessing the environmental impacts of cropping systems and cover crops: Life 
cycle assessment of FAST, a long-term arable farming field experiment. Agricultural Systems 157, 39-50.

R Core Team, 2014. R: A language and environment for statistical computing. R Foundation for Statistical Computing, Vienna, Austria.

Radicetti, E., Baresel, J.P., El-Haddoury, E.J., Finckh, M.R., Mancinelli, R., Schmidt, J.H., Thami Alami, I., Udupa, S.M., van der Heijden, M.G.A., Wittwer, R., Campiglia, E., 2018. Wheat performance with subclover living mulch in different agro-environmental conditions depends on crop management. European Journal of Agronomy 94, 36-45.

Radicetti, E., Mancinelli, R., Moscetti, R., Campiglia, E., 2016. Management of winter cover crop residues under different tillage conditions affects nitrogen utilization efficiency and yield of eggplant (Solanum melanogena L.) in Mediterranean environment. Soil and Tillage Research 155, 329-338.

Rasmussen, J., Ntakos, G., Nielsen, J., Svensgaard, J., Poulsen, R.N., Christensen, S., 2016. Are vegetation indices derived from consumer-grade cameras mounted on UAVs sufficiently reliable for assessing experimental plots? European Journal of Agronomy 74, 75-92.

Reimer, M., Ringselle, B., Bergkvist, G., Westaway, S., Wittwer, R., Baresel, J.P., van der Heijden, M.G.A., Mangerud, K., Finckh, M.R., Brandsæter, L.O., 2019. Interactive Effects of Subsidiary Crops and Weed Pressure in the Transition Period to Non-Inversion Tillage, A Case Study of Six Sites Across Northern and Central Europe. Agronomy 9.

Roesch-McNally, G.E., Basche, A.D., Arbuckle, J.G., Tyndall, J.C., Miguez, F.E., Bowman, T., Clay, R., 2017. The trouble with cover crops: Farmers' experiences with overcoming barriers to adoption. Renewable Agriculture and Food Systems, 1-12.

Schipanski, M.E., Barbercheck, M., Douglas, M.R., Finney, D.M., Haider, K., Kaye, J.P., Kemanian, A.R., Mortensen, D.A., Ryan, M.R., Tooker, J., White, C., 2014. A framework for evaluating ecosystem services provided by cover crops in agroecosystems. Agricultural Systems 125, 12-22.

Schmidt, J., Bergkvist, G., Campiglia, E., Radicetti, E., Wittwer, R., Finckh, M., Hallmann, J., 2017. Effect of tillage, subsidiary crops and fertilisation on plant-parasitic nematodes in a range of agro-environmental conditions within Europe. Annals of Applied Biology 171, 477-489.

Seifert, C.A., Azzari, G., Lobell, D.B., 2018. Satellite detection of cover crops and their effects on crop yield in the Midwestern United States. Environmental Research Letters 13, 064033.

Shelton, R.E., Jacobsen, K.L., McCulley, R.L., 2017. Cover Crops and Fertilization Alter Nitrogen Loss in Organic and Conventional Conservation Agriculture Systems. Front Plant Sci 8, 2260.

Šišić, A., Baćanović-Šišić, J., Karlovsky, P., Wittwer, R., Walder, F., Campiglia, E., Radicetti, E., Friberg, H., Baresel, J.P., Finckh, M.R., 2018. Roots of symptom-free leguminous cover crop and living mulch species harbor diverse Fusarium communities that show highly variable aggressiveness on pea (Pisum sativum). PLoS ONE 13, e0191969.

Skinner, C., Gattinger, A., Krauss, M., Krause, H.M., Mayer, J., van der Heijden, M.G.A., Mader, P., 2019. The impact of long-term organic farming on soil-derived greenhouse gas emissions. Sci Rep 9, 1702.

Stoate, C., Boatman, N.D., Borralho, R.J., Carvalho, C.R., de Snoo, G.R., Eden, P., 2001. Ecological impacts of arable intensification in Europe. Journal of Environmental Management 63, 337-365.

Storr, T., Simmons, R.W., Hannam, J.A., 2019. A UK survey of the use and management of cover crops. Annals of Applied Biology.

Teasdale, J.R., Coffman, C.B., Mangum, R.W., 2007. Potential long-term benefits of notillage and organic cropping systems for grain production and soil improvement. Agronomy Journal 99, 1297-1305. 
Thapa, R., Mirsky, S.B., Tully, K.L., 2018. Cover Crops Reduce Nitrate Leaching in Agroecosystems:A Global Meta-Analysis. J Environ Qual 47, 1400-1411.

Thorup-Kristensen, K., Dresboll, D.B., 2010. Incorporation time of nitrogen catch crops influences the $\mathrm{N}$ effect for the succeeding crop. Soil Use and Management 26, 27-35.

Thorup-Kristensen, K., Magid, J., Jensen, L.S., 2003. Catch crops and green manures as biological tools in nitrogen management in temperate zones. Advances in Agronomy 79, 227-302.

Tilman, D., Cassman, K.G., Matson, P.A., Naylor, R., Polasky, S., 2002. Agricultural sustainability and intensive production practices. Nature 418, 671.

Tonitto, C., David, M.B., Drinkwater, L.E., 2006. Replacing bare fallows with cover crops in fertilizer-intensive cropping systems: A meta-analysis of crop yield and $\mathrm{N}$ dynamics. Agriculture Ecosystems \& Environment 112, 58-72.

Tosti, G., Benincasa, P., Farneselli, M., Guiducci, M., Onofri, A., Tei, F., 2019. Processing Tomato-Durum Wheat Rotation under Integrated, Organic and Mulch-Based No-Tillage Organic Systems: Yield, N Balance and N Loss. Agronomy 9.

Tosti, G., Benincasa, P., Farneselli, M., Pace, R., Tei, F., Guiducci, M., Thorup-Kristensen, K., 2012. Green manuring effect of pure and mixed barley - hairy vetch winter cover crops on maize and processing tomato N nutrition. European Journal of Agronomy 43, 136-146.

Tribouillois, H., Cohan, J.-P., Justes, E., 2015. Cover crop mixtures including legume produce ecosystem services of nitrate capture and green manuring: assessment combining experimentation and modelling. Plant Soil 401, 347-364.

Tsiafouli, M.A., Thebault, E., Sgardelis, S.P., de Ruiter, P.C., van der Putten, W.H., Birkhofer, K., Hemerik, L., de Vries, F.T., Bardgett, R.D., Brady, M.V., Bjornlund, L., Jorgensen, H.B., Christensen, S., D' Hertefeldt, T., Hotes, S., Hol, W.H.G., Frouz, J., Liiri, M., Mortimer, S.R., Setala, H., Tzanopoulos, J., Uteseny, K., Pizl, V., Stary, J., Wolters, V., Hedlund, K., 2015. Intensive agriculture reduces soil biodiversity across Europe. Global Change Biology 21, 973-985.

Tucker, C.J., 1979. Red and photographic infrared linear combinations for monitoring vegetation. Remote sensing of Environment 8, 127-150.

Walder, F., Schlaeppi, K., Wittwer, R., Held, A.Y., Vogelgsang, S., van der Heijden, M.G., 2017. Community profiling of Fusarium in combination with other plant-associated fungi in different crop species using SMRT sequencing. Frontiers in plant science 8, 2019.

Wittwer, R.A., Dorn, B., Jossi, W., Van Der Heijden, M.G., 2017. Cover crops support ecological intensification of arable cropping systems. Scientific reports 7, 41911.

Woods, J., Williams, A., Hughes, J.K., Black, M., Murphy, R., 2010. Energy and the food system. Philosophical Transactions of the Royal Society B-Biological Sciences 365 , 2991-3006. 
Table 1: Statistical ANOVA output demonstrating the effects of the main factors experiment (year), tillage, cover crop and fertilisation and their interaction terms on the assessed variables in maize. $F_{(\mathrm{df1}, \mathrm{df2})}$ values (df1: numerator degrees of freedom; df2: denominator degrees of freedom) and significance level (ns: non-significant; $\left.{ }^{*} \mathbf{p}<0.05 ; * * p<0.01 ; * * * \mathbf{p}<0.001\right) . \mathbf{N N I}=$ Nitrogen Nutrition Index; NeffCC $=\mathbf{N}$ effect from cover crops; max NDVI vegetation period; Growth rate (GRate): mean daily growth rate until half growing season (76 days after sowing).

\begin{tabular}{|c|c|c|c|c|c|c|c|c|c|c|c|c|}
\hline \multirow[b]{2}{*}{ Variables } & \multicolumn{12}{|c|}{ Factors } \\
\hline & Exp & Exp:Block & Tillage (T) & $\begin{array}{l}\text { Cover crop } \\
\text { (CC) }\end{array}$ & $\begin{array}{l}\text { Fertilization } \\
\text { (F) }\end{array}$ & $\mathrm{T} \times \mathrm{CC}$ & $\mathrm{CC} \times \mathrm{F}$ & $T \times F$ & $T \times C C \times F$ & Year $\mathbf{x} T$ & Year $\times$ CC & Year $\mathrm{xF}$ \\
\hline & \multicolumn{12}{|c|}{ Cover crop } \\
\hline Weed cover 60 DAS & ns & ns & ns & $210.4_{(3,60)}{ }^{* * *}$ & ns & ns & $4 \cdot 3_{(3,63)} * *$ & ns & ns & ns & $7.0_{(3,60)} * * *$ & ns \\
\hline Weed biomass spring & $11.3_{(1,12)}{ }^{* *}$ & $\mathrm{~ns}$ & ns & $143.5_{(3,60)} * * *$ & $6.8_{(1,20)}{ }^{*}$ & ns & $4.5_{(3,63)}$ ** & ns & ns & ns & $19.8_{(3,60)}$ *** & ns \\
\hline Cover crop cover 60 DAS & $6.8_{(1,12)}{ }^{*}$ & ns & ns & $29.4_{(3,40)} * * *$ & $8.3_{(1,20)}$ ** & ns & $11.1_{(2,42)}{ }^{* \star *}$ & $6.8(2,20)$ ** & ns & ns & $10.1_{(2,40)}$ *** & $8.0_{(1,20)}$ * \\
\hline Cover crop biomass spring & ns & ns & ns & $139.6_{(2,40)} * * *$ & $4.9_{(1,20)} *$ & ns & ns & ns & ns & ns & ns & ns \\
\hline Cover crop $\mathrm{N}$ content & ns & ns & ns & $236.6_{(2,40)} * * *$ & ns & ns & ns & ns & ns & ns & ns & ns \\
\hline Cover crop $\mathrm{C} / \mathrm{N}$ ratio & ns & ns & ns & $293.6_{(2,40)} * * *$ & ns & ns & $4.8_{(2,42)}{ }^{*}$ & ns & ns & ns & $24.8_{(2,40)}{ }^{* * *}$ & ns \\
\hline \multirow[t]{2}{*}{ Cover crop Ndfa } & ns & ns & ns & 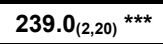 & ns & ns & ns & ns & ns & ns & ns & $\mathrm{ns}$ \\
\hline & \multicolumn{12}{|c|}{ Maize } \\
\hline Weed density after weed control & ns & ns & $6.9_{(2,12)} *$ & ns & ns & ns & ns & $\mathrm{ns}$ & $\mathrm{ns}$ & ns & $\mathrm{ns}$ & $\mathrm{ns}$ \\
\hline Weed biomass after weed control & ns & ns & $28.4_{(2,12)} * * *$ & ns & ns & ns & ns & $\mathrm{ns}$ & ns & $15.9_{(2,12)} * * *$ & ns & $\mathrm{ns}$ \\
\hline Biomass & $25.5_{(1,12)} * * *$ & ns & $17.7_{(2,12)} * * *$ & $50.0_{(3,60)} * * *$ & $75.8_{(1,20)} * * *$ & $8.3_{(6,60)} * * *$ & $5.7_{(3,63)} * *$ & ns & ns & ns & ns & $7.2_{(1,20)} *$ \\
\hline Grain yield & $4.8_{(1,12)} *$ & $\mathrm{~ns}$ & $10.3_{(2,12)}{ }^{* *}$ & $25.9_{(3,60)}$ *** & $42.8_{(1,20)} * * *$ & $3.5_{(6,60)}$ ** & $2.9_{(3,63)^{*}}$ & ns & ns & $\mathrm{ns}$ & $\mathrm{ns}$ & $5.7_{(1,20)^{*}}$ \\
\hline $\mathrm{N}$ uptake & $22 \cdot 1_{(1,12)}$ *** & ns & $27.2_{(2,12)}{ }^{* * *}$ & $131.8_{(3,60)} * * *$ & $253.4_{(1,20)}{ }^{* * *}$ & $7.5_{(6,60)} * * *$ & ns & ns & $2.8_{(6,63)}$ * & ns & $\mathrm{ns}$ & $28.3_{(1,20)} * * *$ \\
\hline NNI & $8.8_{(1,12)}{ }^{*}$ & $\mathrm{~ns}$ & $39.3_{(2,12)}{ }^{* * *}$ & $132.7_{(3,60)} * * *$ & $250.8_{(1,20)}{ }^{* * *}$ & $3 \cdot 9_{(6,60)}$ ** & ns & $\mathrm{ns}$ & ns & ns & ns & $21 \cdot 3_{(1,20)}{ }^{* * *}$ \\
\hline NeffCC & $13.5_{(1,12)}{ }^{* *}$ & $\mathrm{~ns}$ & $17.1_{(2,12)} * * *$ & $95.4_{(2,40)}{ }^{* * *}$ & $\mathrm{~ns}$ & $6.9_{(2,40)}{ }^{* * *}$ & $\mathrm{~ns}$ & $\mathrm{~ns}$ & $4.1_{(4,42)}{ }^{* *}$ & $\mathrm{~ns}$ & $\mathrm{~ns}$ & $\mathrm{~ns}$ \\
\hline \multirow[t]{2}{*}{$\mathrm{N}$ balance } & $5.6_{(1,12)}{ }^{*}$ & $\mathrm{~ns}$ & $13.1_{(2,12)}$ *** & $83.2_{(3,60)}{ }^{* * *}$ & $79.8_{(1,20)}$ *** & ns & ns & $\mathrm{ns}$ & $3.0_{(6,63)}{ }^{*}$ & $\mathrm{~ns}$ & $\mathrm{~ns}$ & $10.2_{(1,20)}{ }^{\star * *}$ \\
\hline & \multicolumn{12}{|c|}{ Maize NDVI (only Experiment II) } \\
\hline $\max N D V I$ & - & ns & $14.9_{(2,6)}{ }^{* *}$ & $38.5_{(3,27)}$ *** & $42.3_{(1,9)}$ *** & $3.5_{(6,27)} *$ & $3.3(3,27)^{*}$ & ns & $\mathrm{ns}$ & - & - & - \\
\hline Growth rate (GRate) & - & ns & $13 \cdot 1_{(2,6)}{ }^{* *}$ & $12.9_{(3,27)}{ }^{* * *}$ & $22.8_{(1,9)} * *$ & $3.6_{(6,27)} * *$ & $3.7_{(3,27)}{ }^{*}$ & $\mathrm{~ns}$ & $\mathrm{~ns}$ & - & - & - \\
\hline Time integrated NDVI (TIN) & - & $\mathrm{ns}$ & $16.3_{(2,6)} * *$ & $42.1_{(3,27)}{ }^{* * *}$ & $102.2_{(1,9)} * * *$ & ns & ns & ns & $\mathrm{ns}$ & - & - & - \\
\hline TIN growth & - & ns & $6.8_{(2,6)} *$ & $26.6_{(3,27)}{ }^{* * *}$ & $37.6_{(1,9)}$ *** & $\mathrm{ns}$ & ns & ns & ns & - & - & - \\
\hline TIN senescence & - & ns & ns & $22.3_{(3,27)} * * *$ & $161.5_{(1,9)}$ *** & ns & ns & ns & ns & - & - & - \\
\hline
\end{tabular}


Table 2: Maize total $\mathbf{N}$ uptake and $\mathbf{N}$ effect from cover crops (NeffC) (mean \pm ci, $n=8)$ for half and norm fertilisation. NeffCC values under half fertilization were calculated in relation to the half $\mathrm{N}$ control plots for each tillage system (light grey), and values under norm

797 (control: no cover crop, RS: oilseed radish, TS: sub. clover, VV: hairy vetch).

\begin{tabular}{|c|c|c|c|c|c|}
\hline Tillage & Cover crop & $\begin{array}{l}\text { N uptake } \\
(\text { kg N ha-1) }\end{array}$ & $\begin{array}{c}\text { NeffCC } \\
\left(k^{\prime} \text { N ha }\right. \\
\end{array}$ & $\begin{array}{l}\text { N uptake } \\
(\text { kg N ha-1) }\end{array}$ & $\begin{array}{c}\text { NeffCC } \\
\left(k^{\prime} \text { N ha }\right. \\
\end{array}$ \\
\hline \multirow{5}{*}{ IT } & & halfN & \multirow[t]{2}{*}{ halfN } & normN & normN \\
\hline & Control & $131 \pm 16$ & & $171 \pm 17$ & $40 \pm 8$ \\
\hline & Oilseed radish (RS) & $165 \pm 17$ & $33 \pm 20$ & $191 \pm 18$ & $20 \pm 6$ \\
\hline & Subclover (TS) & $176 \pm 25$ & $43 \pm 29$ & $215 \pm 23$ & $44 \pm 7$ \\
\hline & Hairy vetch (VV) & $241 \pm 20$ & $109 \pm 27$ & $262 \pm 13$ & $91 \pm 8$ \\
\hline \multirow[t]{4}{*}{ NT } & Control & $133 \pm 19$ & & $176 \pm 27$ & $42 \pm 7$ \\
\hline & Oilseed radish (RS) & $141 \pm 21$ & $7 \pm 7$ & $184 \pm 33$ & $9 \pm 5$ \\
\hline & Subclover (TS) & $186 \pm 34$ & $52 \pm 22$ & $212 \pm 30$ & $36 \pm 5$ \\
\hline & Hairy vetch (VV) & $201 \pm 15$ & $67 \pm 17$ & $222 \pm 37$ & $46 \pm 9$ \\
\hline \multirow[t]{4}{*}{ RT } & Control & $101 \pm 21$ & & $139 \pm 24$ & $38 \pm 11$ \\
\hline & Oilseed radish (RS) & $112 \pm 24$ & $11 \pm 11$ & $148 \pm 13$ & $9 \pm 6$ \\
\hline & Subclover (TS) & $124 \pm 19$ & $23 \pm 12$ & $134 \pm 12$ & $-5 \pm 8$ \\
\hline & Hairy vetch (VV) & $176 \pm 19$ & $76 \pm 8$ & $223 \pm 16$ & $84 \pm 10$ \\
\hline
\end{tabular}



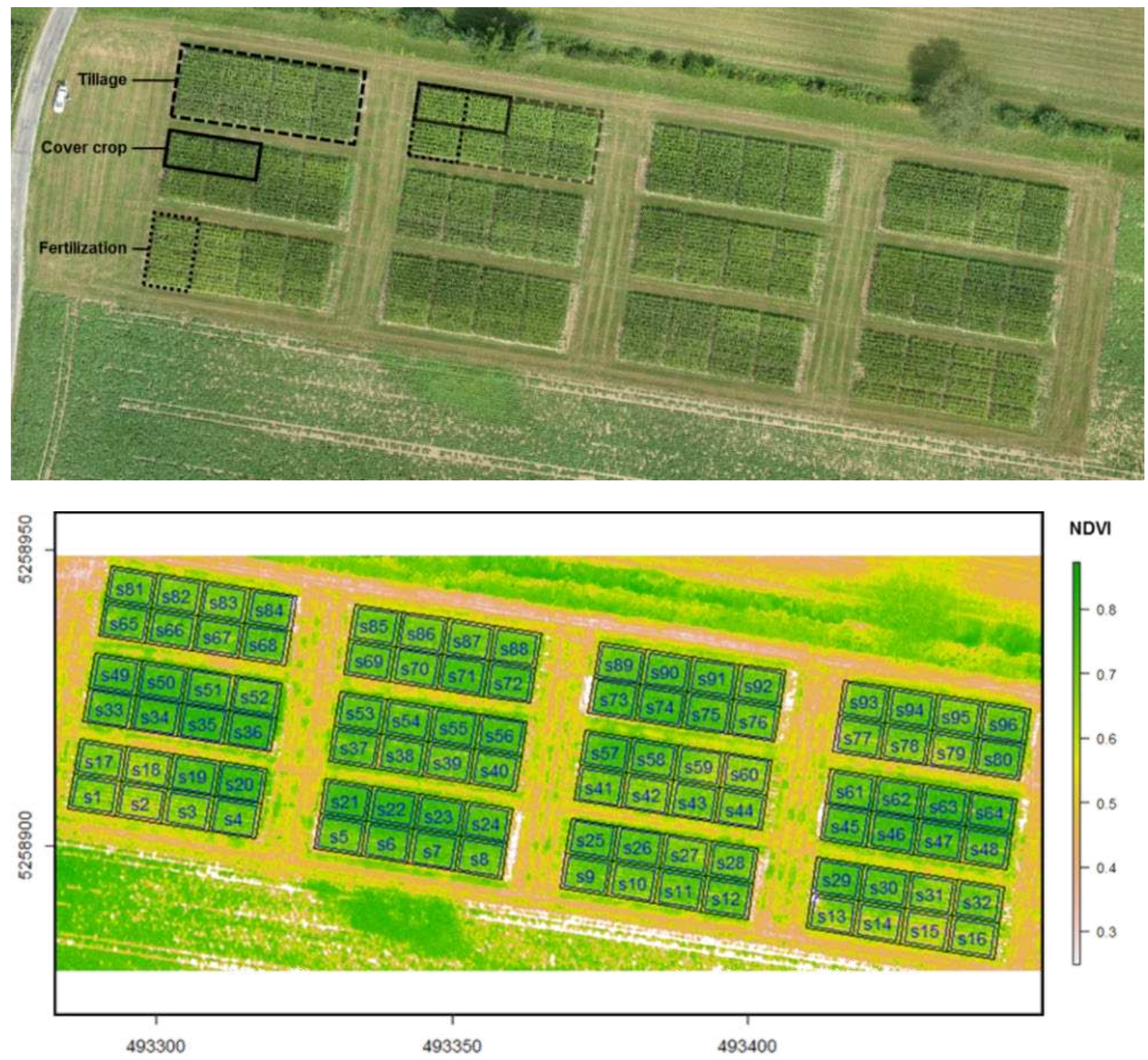

800

801 Fig. 1 Top Aerial picture of experiment II (10.08.2015) computed from drone imagery (eBee AG, 802 SenseFly) with the software Postflight Terra 3D (Pix4D). Arrangement of main plots (tillage) and 803 the crossed-split-plots (cover crop and fertilization) are drawn to illustrate the experimental 804 design. Bottom NDVI index map (10.08.2015) created with the software PostflightTerra 3D 805 (Pix4D, version 4.0.104), which was used to monitor maize growth. 

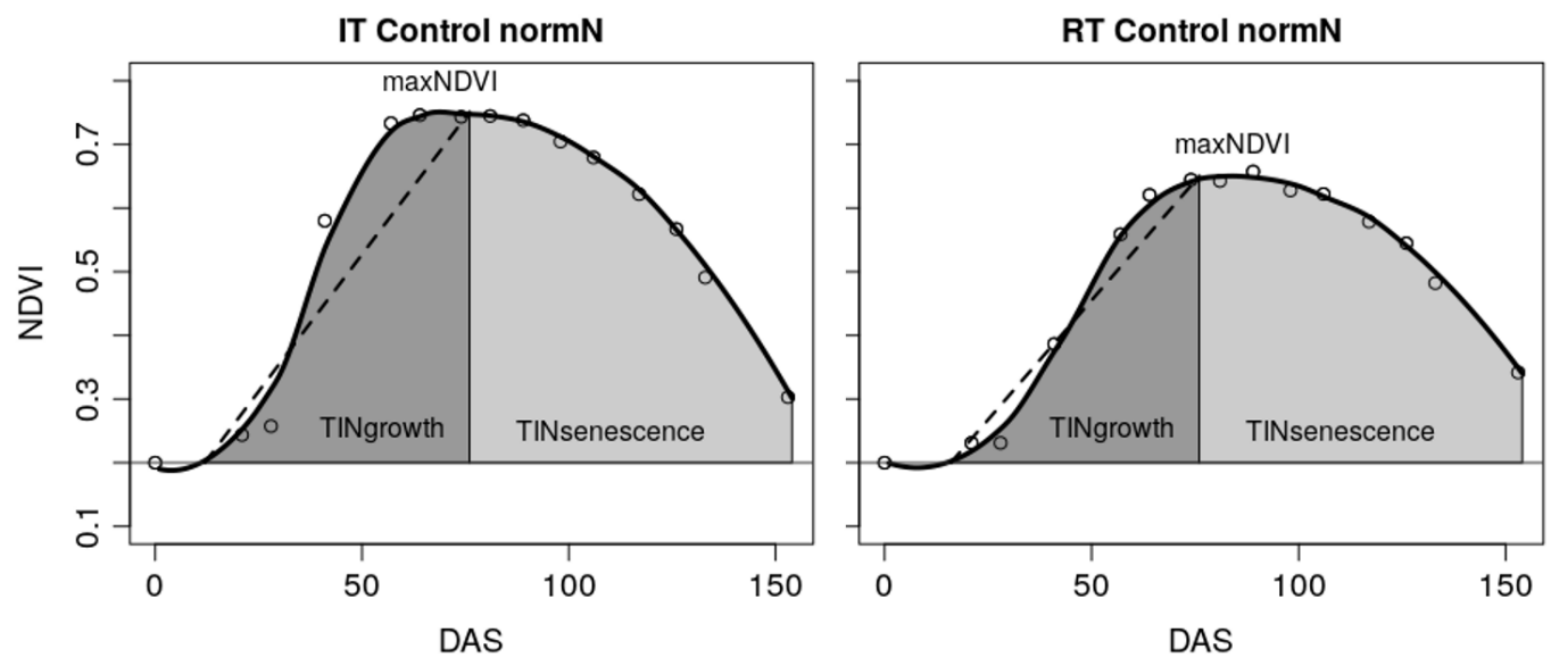

807

808 Fig. 2 Maize growth curves (red) fitted over NDVI measurements for two plots in 2015 and the 809 calculated phenological indexes; maxNDVI, Time Integrated NDVI (TIN, divided in TINgrowth 810 and TINsenescence) and Growth Rate (GRate). 

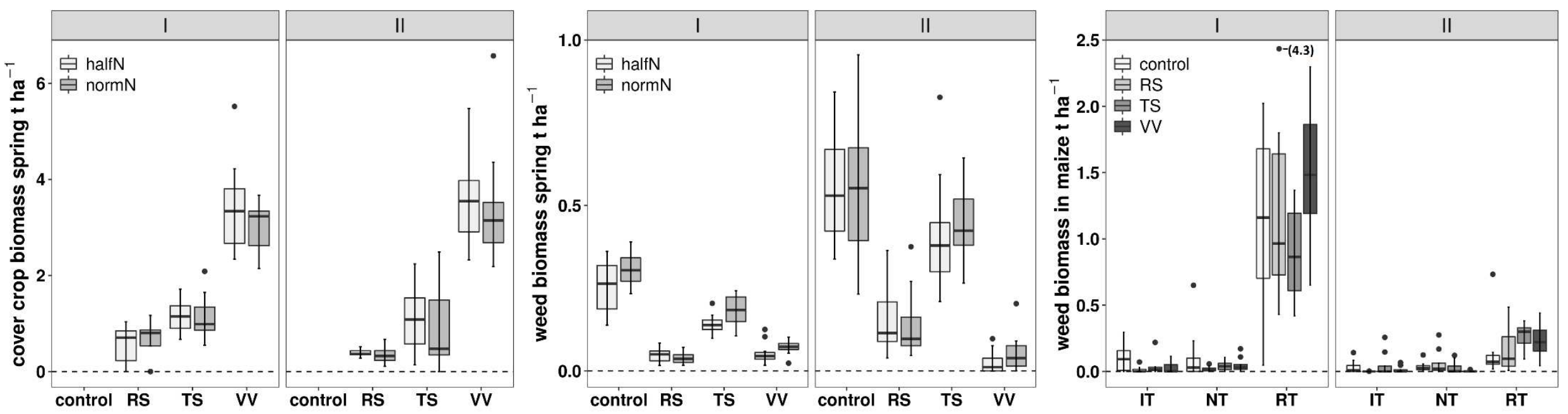

Figure 3: Cover crop biomass and weed biomass at cover crop termination (spring) and weed biomass in the maize crop at flowering. The factor tillage 


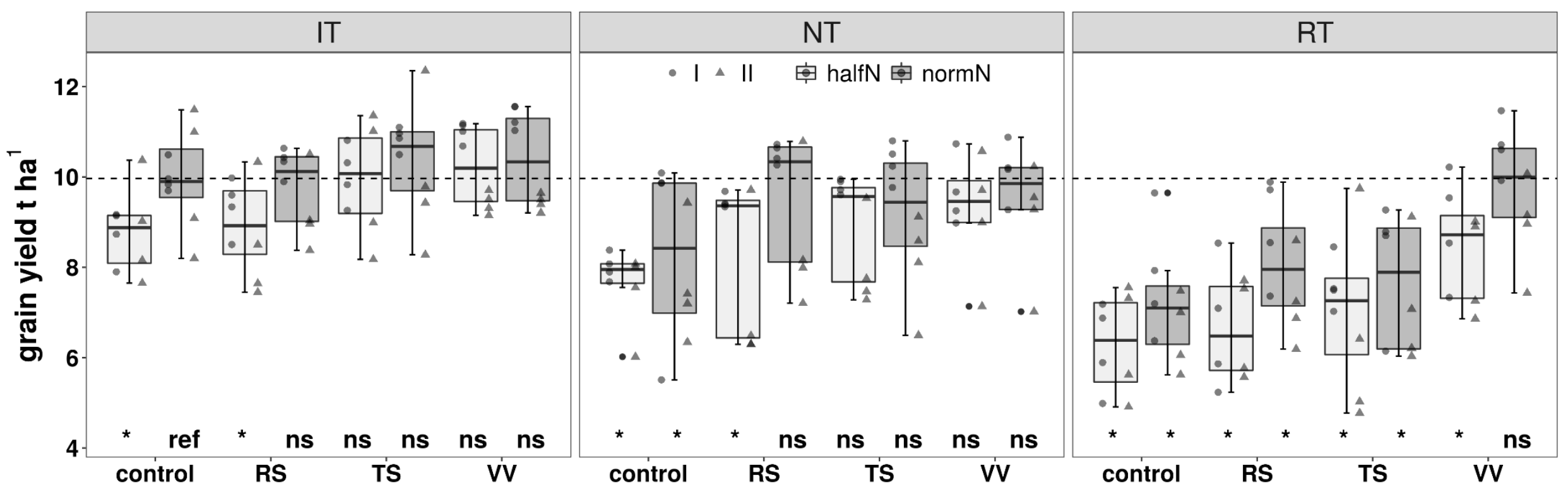

819 Figure 4: Maize grain yield for the main factor combinations. The circles and triangles are the individual values for experiment I and II. The dashed line shows the mean yield level in the reference treatment with intensive tillage, no cover crop and norm fertilisation (ref). * indicate significant difference $(<\mathbf{0 . 0 5})$ compared to the ref treatment, ns not significantly different from ref (contrast with adjusted p-value after Benjamini and Hochberg). fertilization, halfN: half fertilization). 

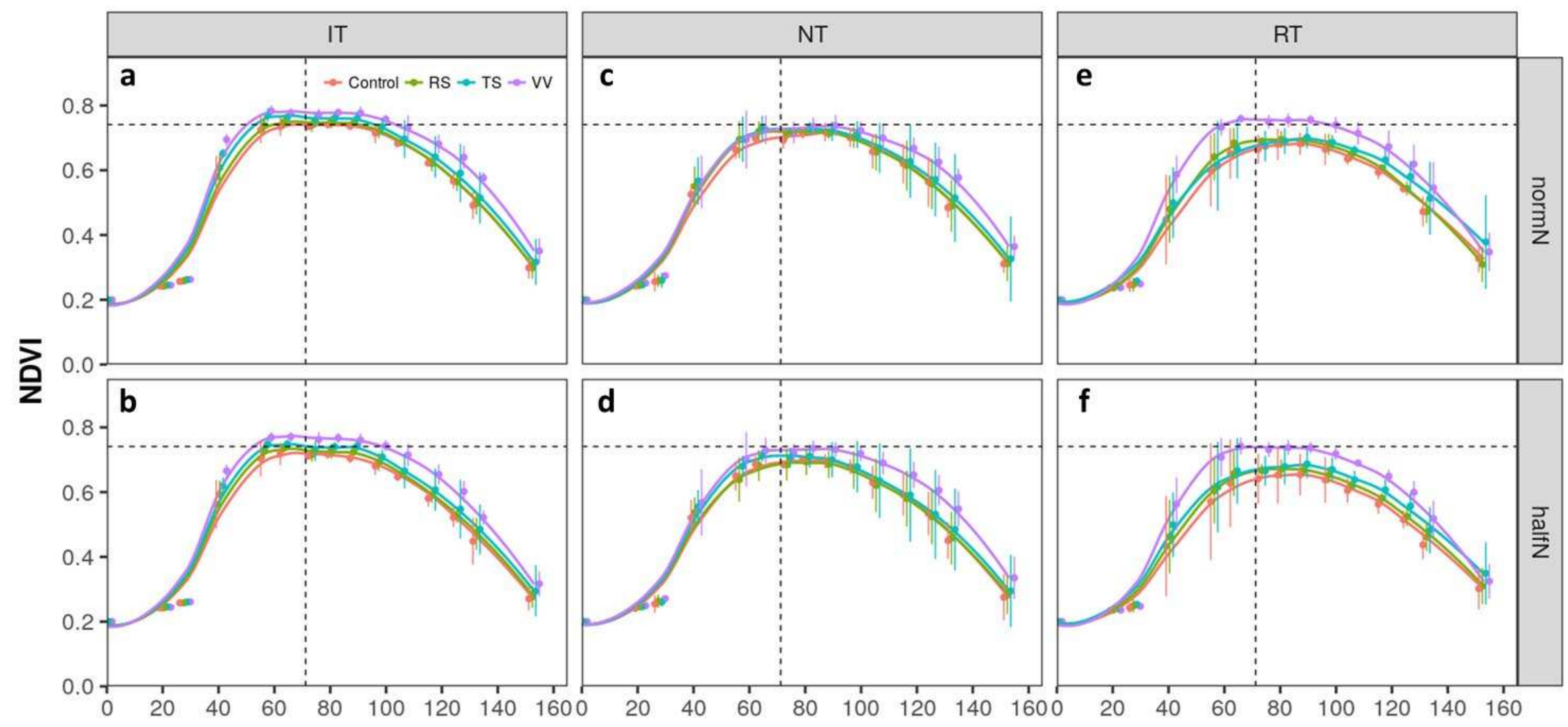

\section{Days After Sowing}

Figure 5: Maize growth curves (NDVI over growing season, mean $\pm c i, n=4)$ with four cover crop treatments $($ red $=$ control; green $=$ oilseed radish $(\mathrm{RS})$;

blue = sub. clover (TS); violet $=$ hairy vetch (VV)) under intensive tillage (IT), no tillage (NT) and reduced tillage (RT) and norm and half fertilization. To 


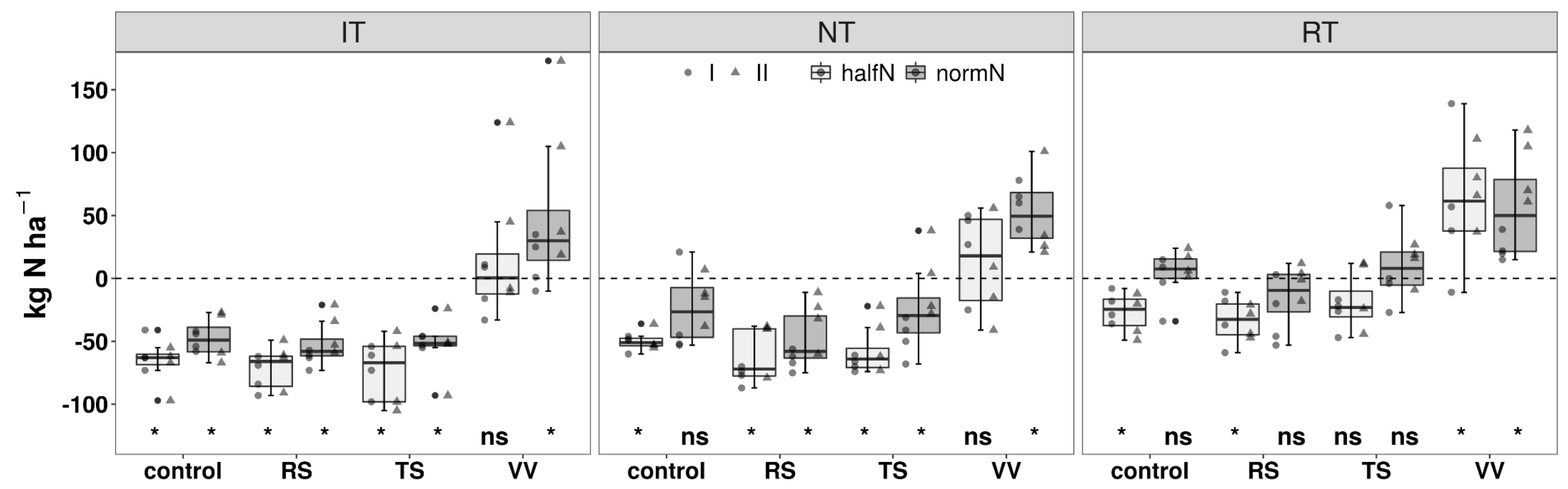

831 Figure 6: Nitrogen balance of maize for all treatment combinations calculated as $\mathrm{N}$ input (Nfert + Nfix) minus $\mathrm{N}$ exported by the grains. Positive values indicate that not all added nitrogen was removed at harvest while negative values indicate that more $\mathbf{N}$ was removed compared to what was added with 